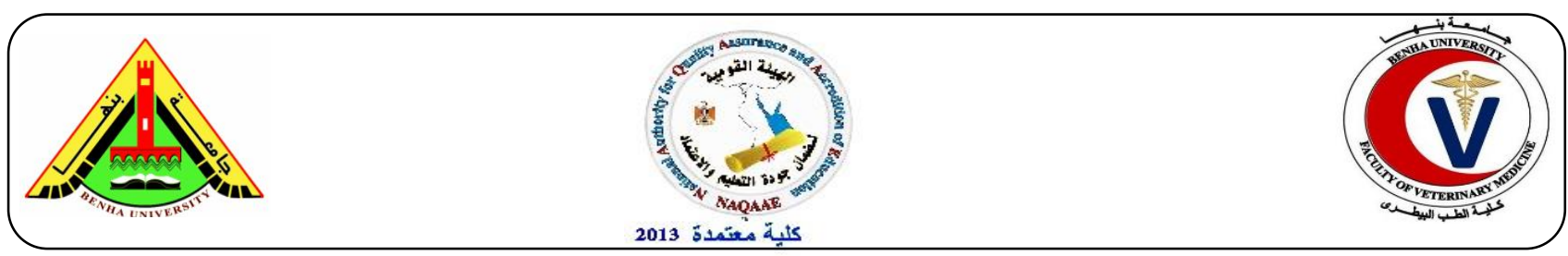

\title{
Impact of some essential oils on the quality aspect and shelf life of meat
}

\author{
Fahim A. Shaltout ${ }^{1}$; Thabet, M.G ${ }^{2}$ and Hanan, A. Koura ${ }^{3}$ \\ ${ }^{1}$ Food Control Department. Faculty of Veterinary Medicine, Benha University \\ ${ }^{2}$ Animal Health Research Institute (Benha Branch-Food Control Department) \\ ${ }^{3}$ B.V.Sc., Cairo University, 2000
}

\begin{abstract}
A B S T R A C T
Plant essential oils (EOs) serve as a "safe" alternative to chemical or synthetic antimicrobials and antioxidants to struggle with the food borne pathogens or spoilage organisms, inhibiting lipid oxidation and thus extend shelf life of ground beef application .In our study, we investigated the effectiveness of thyme oil (thymus vulgaris) at concentrations $(1 \%, 1.5 \%$ and $2 \%)$ and cinnamon oil (cinnamomum zeylanicum) at concentrations $(0.5 \%, 1 \%$ and $1.5 \%)$ as natural preservatives as well as their ability to increase the shelf life of minced meat, and also their effects on chemical , microbial analysis and sensory properties of minced meat when been stored at $2^{\circ} \mathrm{C}$ for 12 days storage period. Obtained results showed that samples treated revealed decreasing of values from chemical, microbial and improving sensory properties than untreated samples (control) ones. Also, thyme oil at concentration $2 \%$ and cinnamon oil at concentration $1.5 \%$ showed best values than others.
\end{abstract}

Keywords: essential oils, thyme oil and cinnamon oil, minced meat

(http://www.bvmi.bu.edu.eg)(BVMJ-33(2): 351-364, 2017)

\section{INTRODUCTION}

Meat has long been known for its nutritive composition which could explain why it is being the first choice sources of animal protein for many people all over the world. Meat has a short shelf life of one day or less at ambient temperature $\left(15-30^{\circ} \mathrm{C}\right)$ and a few days at refrigerated temperature $\left(0-10^{\circ} \mathrm{C}\right)$ due to microbial spoilage of both pathogenic and non-pathogenic microorganisms and/or lipid oxidation (Houben, 2000). Once the animal has been slaughtered, the meat is fabricated into whole sale or retail cuts. Trim and other cuts of meat are then further processed and ground. This increases the surface area of the meat which allows the increased adherence and growth of the bacteria (Skandamis and Nychas, 2001 and Donsi et al., 2011). Meat has a complex physical structure and chemical composition that is very susceptible to oxidation (Rather et al., 2016).

Essential oils are natural, volatile liquid, complex compounds characterized by a strong odor, rarely colored, soluble in lipid and organic solvents.It couldbesynthesizedbyallplantorgans,i.e.buds,f lowers, leaves,stems,twigs, seeds, fruits, root, wood or bark, and are stored in secretary cells, cavities, canals, epidermic cells or glandular trichomes (Bozin et al., 2006) 
Thyme (thymus sp.) has much attention due to its high content and wide spectrum of phenolic compounds, antimicrobial and antioxidant properties, and potential for use in meat and meat products (Guttierrez et al., 2008 ; Barbosa et al., 2009 ; Gutierrez et al., 2009 ; Jayasena and Jo, 2013 ; Bensid et al., 2014). Thyme essential oil also contains a variety of flavonoids, including a pigenin, naringenin, luteolin and thymonin(Stahl Biskup,1991). The volatile oil components of thyme have also been known to have antimicrobial activity against different bacteria and fungi species (Dorman and Deans 2000).

The bark and leaves of Cinnamon are commonly used as spices in the home kitchen and their distilled essential oils or synthetic analogs are used as flavoring agents in the food and beverage industry (Jham et al., 2005). The major compounds in the essential oil of Cinnamomumzeylanicum are cinnamaldehyde, benzaldehyde, limonene, linalool and eugenol (Baratta et al., 1998). PH values showed the effect of microbial load on minced meat as activation effect of microbial load causes protein hydrolysis with appearance of alkyl group, TBARs values is routinely used as an index of lipid oxidation in minced meat in store and TVN values attributed to the breakdown of proteins as a result of activity of microbial strains and proteolyticenzeymes.

The objective of thepresent study was the antioxidant as well as the antimicrobial effectiveness of both thyme and cinnamon oils on quality of fresh minced meat during storage at $2^{\circ} \mathrm{C}$ for 12 days.

\section{Materials and methods}

Three and half $\mathrm{Kg}$ of fresh meat were purchased immediately after slaughter from butcher shops in Kalubiya Governorate and was directly minced and packed in clean polyethylene bags. Then were transported directly in insulated and iced containers to microbiology laboratory (Animal Health Research Institute), Benha,Al-Kalubiya, Egypt.Minced meat sample are divided to two minor groups of treated and untreated (control) ones. The treated groups were divided in to 6 groups (300 $\mathrm{g}$ of each) that mixed with thyme at concentrations $\left(\left(\mathrm{T}_{1}\right) 1 \%\right.$, $\left(\mathrm{T}_{2}\right) 1.5 \%$ and $\left(\mathrm{T}_{3}\right) 2 \%$ ) and cinnamon at concentrations $\left[\left(\mathrm{T}_{4}\right) 0.5 \%,\left(\mathrm{~T}_{5}\right) 1 \%\right.$ and $\left(\mathrm{T}_{6}\right)$ $1.5 \%$ ]. All groups were stored at $2^{\circ} \mathrm{C}$ and examined periodically every 3 days for chemically, microbiologically and sensory. The experiment was conducted in triplicate for 12 days of storage.

\section{1) Chemical analysis:}

a- Measurement of $\mathrm{pH}$ according to ISO (1979).

b- Measurement of thiobarbituric acid (TBA) value, the thiobarbituric acid (TBA) assay was carried out according to the procedure of Vyncke (1970).

c- Measurement of total volatile nitrogen (TVN) the total volatile nitrogen (TVN) measurement was carried out according to the procedure ofFAO, (1980).

2) Microbiological analysis:

Preparation of sample, from each group, $10 \mathrm{~g}$ of meat were taken randomly and aseptically using sterile forceps and scissors, the removed samples were placed in a sterile homogenizer flask contained $45 \mathrm{ml}$ of $(0.1 \%)$ peptone water. The content of each flask were homogenized at $14000 \mathrm{rpm}$ for 2.5 minutes for obtaining a dilution of $10^{-1}$, from which $1 \mathrm{ml}$ was transferred with a sterile pipette to a sterile test tube containing $9 \mathrm{ml}$ of $(0.1)$ peptone water, from which a decimal serial dilution were prepared in a sequential manner up to $10^{-}$, to cover all expected range of samples contamination. For microbial count, colonies were counted and recorded in colony forming units per gram (cfu/g) of meat sampled using the formula: $\mathrm{cfu} / \mathrm{g}=$ level of 
dilution plated $\times$ number of colonies counted / volume plated. These were further expressed in mean colony forming units per gram (mean $\mathrm{cfu} / \mathrm{g}$ ) and converted to $\log ^{10}$ base values $\left(\log { }^{10} \mathrm{cfu} / \mathrm{g}\right)$.

a)Aerobic Plate Counts (APC), according to ICMSF (1996).

b)Enterobacteriaceae Count (EBC),according to ICMSF (1996).

c) Coliform count, according to APHA (1985).

\section{3) Sensory Evaluation:}

It was carried out at the third day of the experiment according to Pearson and Tauber (1984). A 9 point hedonic scale $(9=$ Excellent, $8=$ Very very good, $7=$ Very good, $6=$ Good, 5=Medium, 4=Fair, 3=Poor, 2=Very poor, $1=$ Very very poor) was used for the evaluation of the overall acceptability.

4) Statistical Analysis:

ANOVA was carried out on data of thesensory, chemical and microbiological evaluations.Data are expressed as mean+SE (Gomez and Gomez, 1984).

\section{RESULTS}

As shown in table (1) $\mathrm{pH}$ values at control samples were $6.65,6.95,6.99,7.03 \& 7.05$, at 0 , 3rd,6th,9th \& 12th day of storage period, respectively. Samples treated by thyme oil the $\mathrm{pH}$ values at concentration $1 \%$ (T1) were $6.65,6.80,6.77,6.68 \& 6.75$; concentration $1.5 \%$ (T2) $\mathrm{pH}$ values were $6.65,6.83,6.81$, $6.78 \& 6.72$ and concentration $2 \%$ (T3) $\mathrm{pH}$ values were $6.65,6.39,6.37,6.31 \& 6.26$, at 0 , 3rd day,6th day,9th day\&12th day of storage period, respectively. By using cinnamon (C. zeylanicum) oil the $\mathrm{pH}$ values at concentration $0.5 \%$ (T4) were $6.65,6.82$, $6.79,6.74 \& 6.70$; at concentration $1 \%$ (T5) values were $6.65,6.80,6.77,6.72 \& 6.66$ and at concentration $1.5 \%$ (T6) $\mathrm{pH}$ values were $6.65,6.33,6.31,6.28 \& 6.26$, at 0 , 3rd day, 6th day, 9th day\&12th day of storage period, respectively.
As shown in table (2) results showed that TBA values at control samples were $0.140,0.168,0.178,0.190 \& 0.221$ at 0 day, 3rd day, 6th day, 9th day\&12th day of storage period, respectively. By using thyme oil at concentration $1 \%$ (T1) the TBA reactive substance values were $0.140,0.152,0.161$, $0.172 \& 0.177$; using concentration $1.5 \%$ (T2) TBA values were $0.138,0.163,0.176,0.182$ \& 0.191 and using concentration $2 \%$ (T3) TBA values were $0.137,0.140,0.140,0.142$ $\& 0.143$, at 0 day, 3th day, 6th day,9th day \& 12th day, respectively. By using cinnamon oil at concentration $0.5 \%$ (T4) TBA values were $0.140,0.152,0.161,0.172 \& 0.186$; using concentration 1\% (T5) TBA values were $0.139,0.163,0.176,0.182 \& 0.195$ and using concentration $1.5 \%$ (T6) TBA values were $0.139,0.140,0.140,0.142 \& 0.148$. at 0 day, 3rd day,6th day,9th day and 12th day of storage period, respectively.

As shown in table (3) at control sample TVN values were $6.25,39.8,58.2,72.44 \& 84.21$, at 0 day, 3rd day, 6th day, 9th day\&12th day of storage period, respectively. At samples treated with thyme oil at concentration $1 \%$ (T1) TVN values were $6.25,18.23,27.1$, $35.22 \& 44.22$; at concentration $1.5 \%$ (T2) TVN values were $6.25,18.1,26.4,31.1 \& 41.1$ and at concentration $2 \%$ (T3) TVN values were $6.24,16.2,25.1,28.65 \& 35.21$, at 0 day, $3^{\text {rd }}$ day, $6^{\text {th }}$ day, $9^{\text {th }}$ day $\& 12^{\text {th }}$ day of storage period, respectively. By using cinnamon oil at concentration $0.5 \%$ (T4) TVN values were $6.25,18.7,28.8,36.1 \& 50.12$; at concentration $1 \%$ (T5) TVN values were $6.25, \quad 17.99, \quad 26.9, \quad 35.4 \& 45.14$ and at concentration $1.5 \%$ (T6) TVN values were $6.25,16.4,26.1,31.3 \& 35.42$, at 0 day, $3^{\text {rd }}$ day, $6^{\text {th }}$ day, $9^{\text {th }}$ day $\& 12^{\text {th }}$ day of storage period, respectively.

As shown in table (4) results showed that the APC values of control minced meat samples were $5.19 \times 10^{5}, 6.11 \times 10^{7}, 4.15 \times 10^{9}, 2.25 \times 10^{10}$ 
$\& 2.33 \times 10^{12}$, at 0 day, $3^{\text {rd }}$ day, $6^{\text {th }}$ day, $9^{\text {th }}$ day $\& 12^{\text {th }}$ day of storage period, respectively. By using thyme oil at concentration 1\% (T1) APC values were $5.19 \times 10^{5}, 7.63 \times 10^{6}$, $6.25 \times 10^{7}, \quad 5.15 \times 10^{9} \& \quad 5.10 \times 10^{10}$; $\quad$ at concentration $1.5 \%$ (T2) APC values were $5.19 \times 10^{5}, \quad 4.53 \times 10^{6}, \quad 5.11 \times 10^{7}, \quad 4.22 \times 10^{8} \&$ $3.13 \times 10^{9}$. and at concentration $2 \%$ (T3) APC were $5.18 \times 10^{5}, \quad 3.73 \times 10^{6}, \quad 3.15 \times 10^{7}$, $5.89 \times 10^{8} \& 2.15 \times 10^{8}$, at 0 day, $3^{\text {rd }}$ day, $6^{\text {th }}$ day, $9^{\text {th }}$ day $\& 12^{\text {th }}$ day of storage period, respectively. By using cinnamon oil at concentration $0.5 \%$ (T4) APC values were $5.19 \times 10^{5}, \quad 8.53 \times 10^{6}, \quad 6.12 \times 10^{7}, \quad 5.15 \times 10^{8} \&$ $5.14 \times 10^{10}$; at concentration $1 \%(\mathrm{~T} 5)$ APC values were $5.19 \times 10^{5}, 7.93 \times 10^{6}, 6.10 \times 10^{8}$, $5.15 \times 10^{8} \& 4.32 \times 10^{9}$ and at concentration $1.5 \%$ (T6) APC values were $5.19 \times 10^{5}$, $5.12 \times 10^{6}, 4.14 \times 10^{8}, 3.15 \times 10^{8} \& 2.16 \times 10^{9}$, at 0 day, $3^{\text {rd }}$ day, $6^{\text {th }}$ day, $9^{\text {th }}$ day $\& 12^{\text {th }}$ day of storage period, respectively.

As shown in table (5) results showed that the enterobacteriacea count EBC at control sample was $9.32 \times 10^{3}, 7.24 \times 10^{4}, 8.15 \times 10^{5}$, $4.25 \times 10^{6} \& 3.25 \times 10^{8}$, at 0 day, $3^{\text {rd }}$ day, $6^{\text {th }}$ day, $9^{\text {th }}$ day $\& 12^{\text {th }}$ day of storage period, respectively. By using thyme oil at concentration $1 \%$ (T1) EBC was $9.32 \times 10^{3}$, $7.04 \times 10^{4}, 7.12 \times 10^{5}, 6.45 \times 10^{5} \& 6.25 \times 10^{6}$; at concentration $1.5 \%$ (T2) EBC was $9.32 \times 10^{3}$, $7.03 \times 10^{4}, 4.11 \times 10^{5}, 9.25 \times 10^{4} \& 4.25 \times 10^{5}$ and at concentration $2 \%$ (T3) EBC was $9.32 \times 10^{3}$, $6.81 \times 10^{4}, 8.65 \times 10^{4}, 8.25 \times 10^{3} \& 5.25 \times 10^{4}$, at 0 day, $3^{\text {rd }}$ day, $6^{\text {th }}$ day, $9^{\text {th }}$ day $\& 12^{\text {th }}$ day of storage period, respectively. \%). By using cinnamon oil at concentration $0.5 \%$ (T4) (EBC) was $9.32 \times 10^{3}, 7.24 \times 10^{4}, 7.24 \times 10^{5}$, $5.27 \times 10^{5} \& 8.95 \times 10^{6}$; at concentration $1 \%$ (T5) EBC was $9.32 \times 10^{3}, \quad 7.01 \times 10^{4}$, $7.15 \times 10^{5}, \quad 2.25 \times 10^{5} \& 3.25 \times 10^{6} \quad ; \quad$ at concentration $1.5 \%$ (T6) EBC was $9.32 \times 10^{3}$, $6.92 \times 10^{4}, 8.95 \times 10^{4}, 6.25 \times 10^{4} \& 4.35 \times 10^{5}$. At 0 day, $3^{\text {rd }}$ day, 6th day, $9^{\text {th }}$ day $\& 12^{\text {th }}$ day of storage period, respectively.

As shown in table (6) results showed that coliform count at control samples was $6.45 \times 10^{3}, \quad 4.23 \times 10^{5}, \quad 3.45 \times 10^{6}, \quad 5.53 \times 10^{7} \&$ $6.45 \times 10^{8}$, at 0 day, $3^{\text {rd }}$ day, $6^{\text {th }}$ day, $9^{\text {th }}$ day $\& 12^{\text {th }}$ day of storage period, respectively. By using thyme oil at concentration $1 \%$ (T1) coli form count was $6.45 \times 10^{3}, \quad 3.21 \times 10^{5}, \quad 2.45 \times 10^{5}$, $6.13 \times 10^{5} \& 6.15 \times 10^{6}$; at concentration $1.5 \%$ (T2) coliform count was $6.45 \times 10^{3}, 4.53 \times 10^{4}$, $3.35 \times 10^{5}, 3.03 \times 10^{5} \& 5.45 \times 10^{6}$ and coliform count at concentration $2 \%$ (T3)was $6.25 \times 10^{3}$, $3.23 \times 10^{4}, 2.15 \times 10^{4}, 8.53 \times 10^{5} \& 4.45 \times 10^{5}$, at 0 day, $3^{\text {rd }}$ day, $6^{\text {th }}$ day, $9^{\text {th }}$ day $\& 12^{\text {th }}$ day of storage period, respectively. By using cinnamon oil at concentration $0.5 \%$ (T4) coliform count was $6.45 \times 10^{3}, 4.13 \times 10^{4}$, $5.25 \times 10^{5}, \quad 9.23 \times 10^{5} \& 6.25 \times 10^{6}$; $\quad$ at concentration $1 \%$ (T5) coliform count was $6.45 \times 10^{3}, \quad 2.43 \times 10^{4}, \quad 3.15 \times 10^{5}$, $2.44 \times 10^{5} \& 6.05 \times 10^{6}$ and at concentration $1.5 \%$ (T6) coliform count was $6.45 \times 10^{3}$, $4.12 \times 10^{4}, 6.45 \times 10^{5}, 5.63 \times 10^{5} \& 5.55 \times 10^{6}$, at 0 day, $3^{\text {rd }}$ day, $6^{\text {th }}$ day, $9^{\text {th }}$ day $\& 12^{\text {th }}$ day of storage period, respectively.

As shown in table (7) results shown that sensory properties of different treated minced beef samples during cold storage $\left(2^{\circ} \mathrm{C}\right)$ were enhanced by using thyme and cinnamon oils compared to the untreated (control) samples at0 day, $3^{\text {rd }}$ day, $6^{\text {th }}$ day, $9^{\text {th }}$ day and $12^{\text {th }}$ day of the storage period, respectively. Generally, samples containing $2 \%$ thyme oil and $1.5 \%$ cinnamon oil, demonstrated the highest enhancement of sensory attributes, while the samples treated with $1 \%$ of thyme and $0.5 \%$ cinnamon oils demonstrated lower enhancement. 
Table (1): Mean PH values of the examined samples of minced meat stored at $2^{\circ} \mathrm{C}$ (Mean $\pm \mathrm{SE}$ ).

\begin{tabular}{|l|c|c|c|c|c|}
\hline \multirow{2}{*}{ Storage days } & \multicolumn{5}{|c|}{$\mathrm{pH}$ values \pm SE } \\
\cline { 2 - 6 } & 0 & 3 & 6 & 9 & 12 \\
\hline Control & $6.65 \pm 0.02^{\mathrm{a}}$ & $6.95 \pm 0.01^{\mathrm{a}}$ & $6.99 \pm 0.02^{\mathrm{ab}}$ & $7.03 \pm 0.02^{\mathrm{c}}$ & $7.05 \pm 0.03^{\mathrm{d}}$ \\
\hline Thyme 1\%(T1) & $6.65 \pm 0.02^{\mathrm{a}}$ & $6.80 \pm 0.01^{\mathrm{a}}$ & $6.77 \pm 0.01^{\mathrm{ab}}$ & $6.68 \pm 0.01^{\mathrm{c}}$ & $6.75 \pm 0.01^{\mathrm{d}}$ \\
\hline Thyme 1.5\%(T2) & $6.65 \pm 0.02^{\mathrm{a}}$ & $6.83 \pm 0.03^{\mathrm{a}}$ & $6.81 \pm 0.01^{\mathrm{ab}}$ & $6.78 \pm 0.01^{\mathrm{c}}$ & $6.72 \pm 0.01^{\mathrm{d}}$ \\
\hline Thyme 2\%(T3) & $6.65 \pm 0.02^{\mathrm{a}}$ & $6.39 \pm 0.04^{\mathrm{a}}$ & $6.37 \pm 0.01^{\mathrm{ab}}$ & $6.31 \pm 0.01^{\mathrm{c}}$ & $6.26 \pm 0.01^{\mathrm{d}}$ \\
\hline C. zeylanicum 0.5\%(T4) & $6.65 \pm 0.02^{\mathrm{a}}$ & $6.82 \pm 0.01^{\mathrm{a}}$ & $6.79 \pm 0.02^{\mathrm{ab}}$ & $6.74 \pm 0.01^{\mathrm{b}}$ & $6.70 \pm 0.01^{\mathrm{c}}$ \\
\hline C. zeylanicum 1\%(T5) & $6.65 \pm 0.02^{\mathrm{a}}$ & $6.80 \pm 0.03^{\mathrm{a}}$ & $6.77 \pm 0.01^{\mathrm{ab}}$ & $6.72 \pm 0.01^{\mathrm{b}}$ & $6.66 \pm 0.01^{\mathrm{c}}$ \\
\hline C. zeylanicum 1.5\%(T6) & $6.65 \pm 0.02^{\mathrm{a}}$ & $6.33 \pm 0.02^{\mathrm{a}}$ & $6.31 \pm 0.01^{\mathrm{ab}}$ & $6.28 \pm 0.01^{\mathrm{b}}$ & $6.26 \pm 0.01^{\mathrm{c}}$ \\
\hline
\end{tabular}

Values with different letters within the same row differed significantly at $(\mathrm{P}<0.05)$.

Table (2): Mean values of thiobarbituric acid reactive substances (TBARs) of examined minced meat during cold storage at $2^{\circ} \mathrm{C}(\mathrm{Mean} \pm \mathrm{SE})$.

\begin{tabular}{|c|c|c|c|c|c|}
\hline \multirow{2}{*}{ Storage days } & \multicolumn{5}{|c|}{ TBA mg Malonaldehyde/Kg \pm SE } \\
\cline { 2 - 6 } & 0 & 3 & 6 & 9 & 12 \\
\hline Control & $0.140 \pm 0.01^{\mathrm{a}}$ & $0.168 \pm 0.02^{\mathrm{b}}$ & $0.178 \pm 0.01^{\mathrm{c}}$ & $0.190 \pm 0.01^{\mathrm{c}}$ & $0.221 \pm 0.01^{\mathrm{d}}$ \\
\hline T1 & $0.140 \pm 0.01^{\mathrm{a}}$ & $0.152 \pm 0.01^{\mathrm{a}}$ & $0.161 \pm 0.01^{\mathrm{b}}$ & $0.172 \pm 0.01^{\mathrm{c}}$ & $0.177 \pm 0.01^{\mathrm{c}}$ \\
\hline T2 & $0.138 \pm 0.02^{\mathrm{a}}$ & $0.163 \pm 0.02^{\mathrm{b}}$ & $0.176 \pm 0.01^{\mathrm{b}}$ & $0.182 \pm 0.02^{\mathrm{b}}$ & $0.191 \pm 0.01^{\mathrm{c}}$ \\
\hline T3 & $0.137 \pm 0.01^{\mathrm{a}}$ & $0.140 \pm 0.01^{\mathrm{a}}$ & $0.140 \pm 0.00^{\mathrm{a}}$ & $0.142 \pm 0.01^{\mathrm{b}}$ & $0.143 \pm 0.02^{\mathrm{b}}$ \\
\hline T4 & $0.140 \pm 0.01^{\mathrm{a}}$ & $0.152 \pm 0.01^{\mathrm{a}}$ & $0.161 \pm 0.01^{\mathrm{b}}$ & $0.172 \pm 0.01^{\mathrm{c}}$ & $0.186 \pm 0.02^{\mathrm{d}}$ \\
\hline T5 & $0.139 \pm 0.02^{\mathrm{a}}$ & $0.163 \pm 0.02^{\mathrm{b}}$ & $0.176 \pm 0.01^{\mathrm{b}}$ & $0.182 \pm 0.02^{\mathrm{b}}$ & $0.195 \pm 0.01^{\mathrm{c}}$ \\
\hline T6 & $0.139 \pm 0.01^{\mathrm{a}}$ & $0.140 \pm 0.01^{\mathrm{a}}$ & $0.140 \pm 0.00^{\mathrm{a}}$ & $0.142 \pm 0.01^{\mathrm{b}}$ & $0.148 \pm 0.02^{\mathrm{c}}$ \\
\hline
\end{tabular}

Values with different letters within the same row differed significantly at $(\mathrm{P}<0.05)$.

Table (3): Mean values of total volatile nitrogen (TVN) of examined minced meat stored at $2{ }^{\circ} \mathrm{C}$ (Mean \pm SE).

\begin{tabular}{|l|c|c|c|c|c|}
\hline \multirow{2}{*}{ Storage days } & \multicolumn{4}{|c|}{ TVN values } \\
\cline { 2 - 6 } & 0 & 3 & 6 & 9 & 12 \\
\hline Control & $6.25 \pm 1.35$ & $39.80 \pm 1.7$ & $58.20 \pm 1.22$ & $72.44 \pm 1.37$ & $84.21 \pm 1.31$ \\
\hline Thyme 1\% (T1) & $6.25 \pm 1.34$ & $18.23 \pm 1.8$ & $27.1 \pm 1.3$ & $35.22 \pm 1.3$ & $44.22 \pm 1.68$ \\
\hline Thyme 1.5\% (T2) & $6.25 \pm 1.32$ & $18.1 \pm 1.55$ & $26.4 \pm 1.32$ & $31.1 \pm 1.25$ & $41.10 \pm 1.70$ \\
\hline Thyme 2\% (T3) & $6.24 \pm 1.25$ & $16.2 \pm 1.33$ & $25.1 \pm 1.22$ & $28.65 \pm 1.15$ & $35.21 \pm 1.30$ \\
\hline C. zeylanicum0.5\% (T4) & $6.25 \pm 1.35$ & $18.70 \pm 1.5$ & $28.8 \pm 1.12$ & $36.1 \pm 1.15$ & $50.12 \pm 1.31$ \\
\hline C. zeylanicum 1\% (T5) & $6.25 \pm 1.35$ & $17.99 \pm 1.1$ & $26.9 \pm 1.2$ & $35.4 \pm 1.45$ & $45.14 \pm 1.45$ \\
\hline C. zeylanicum 1.5\% (T6) & $6.25 \pm 1.35$ & $16.4 \pm 1.45$ & $26.1 \pm 1.4$ & $31.3 \pm 1.22$ & $35.42 \pm 1.15$ \\
\hline
\end{tabular}

TVN $20 \mathrm{mg} / 100$ gm raw minced beef (EOS, 2005) $+(\mathrm{P}<0.05)$.

Table (4): Changes in aerobic plate count (APC) of examined minced meat during cold storage at $2^{\circ} \mathrm{C}$

\begin{tabular}{|l|c|c|c|c|c|}
\hline \multirow{2}{*}{ Storage days } & \multicolumn{5}{c|}{ ( APC) log cfu /g \pm SE } \\
\cline { 2 - 6 } & 0 & 3 & 6 & 9 & 12 \\
\hline Control & $5.19 \times 10^{5}$ & $6.11 \times 10^{7}$ & $4.15 \times 10^{9}$ & $2.25 \times 10^{10}$ & $2.33 \times 10^{12}$ \\
\hline Thyme 1\%(T1) & $5.19 \times 10^{5}$ & $7.63 \times 10^{6}$ & $6.25 \times 10^{7}$ & $5.15 \times 10^{9}$ & $5.10 \times 10^{10}$ \\
\hline Thyme 1.5\% (T2) & $5.19 \times 10^{5}$ & $4.53 \times 10^{6}$ & $5.11 \times 10^{7}$ & $4.22 \times 10^{8}$ & $3.13 \times 10^{9}$ \\
\hline Thyme 2\% (T3) & $5.18 \times 10^{5}$ & $3.73 \times 10^{6}$ & $3.15 \times 10^{7}$ & $2.89 \times 10^{8}$ & $2.15 \times 10^{8}$ \\
\hline C. zeylanicum 0.5\% (T4) & $5.19 \times 10^{5}$ & $8.53 \times 10^{6}$ & $6.12 \times 10^{7}$ & $5.15 \times 10^{8}$ & $5.14 \times 10^{10}$ \\
\hline C. zeylanicum 1\%(T5) & $5.19 \times 10^{5}$ & $7.93 \times 10^{6}$ & $6.10 \times 10^{8}$ & $5.15 \times 10^{8}$ & $4.32 \times 10^{9}$ \\
\hline C. zeylanicum 1.5\%(T5) & $5.19 \times 10^{5}$ & $5.21 \times 10^{6}$ & $4.14 \times 10^{8}$ & $3.15 \times 10^{8}$ & $2.16 \times 10^{9}$ \\
\hline
\end{tabular}

Values with different letters within the same row differed significantly at $(\mathrm{P}<0.05)$. 
Table (5): Changes in enterobacteriaceae count of examined minced meat during cold storage at $2^{\circ} \mathrm{C}$ (Mean \pm $\mathrm{SE})$.

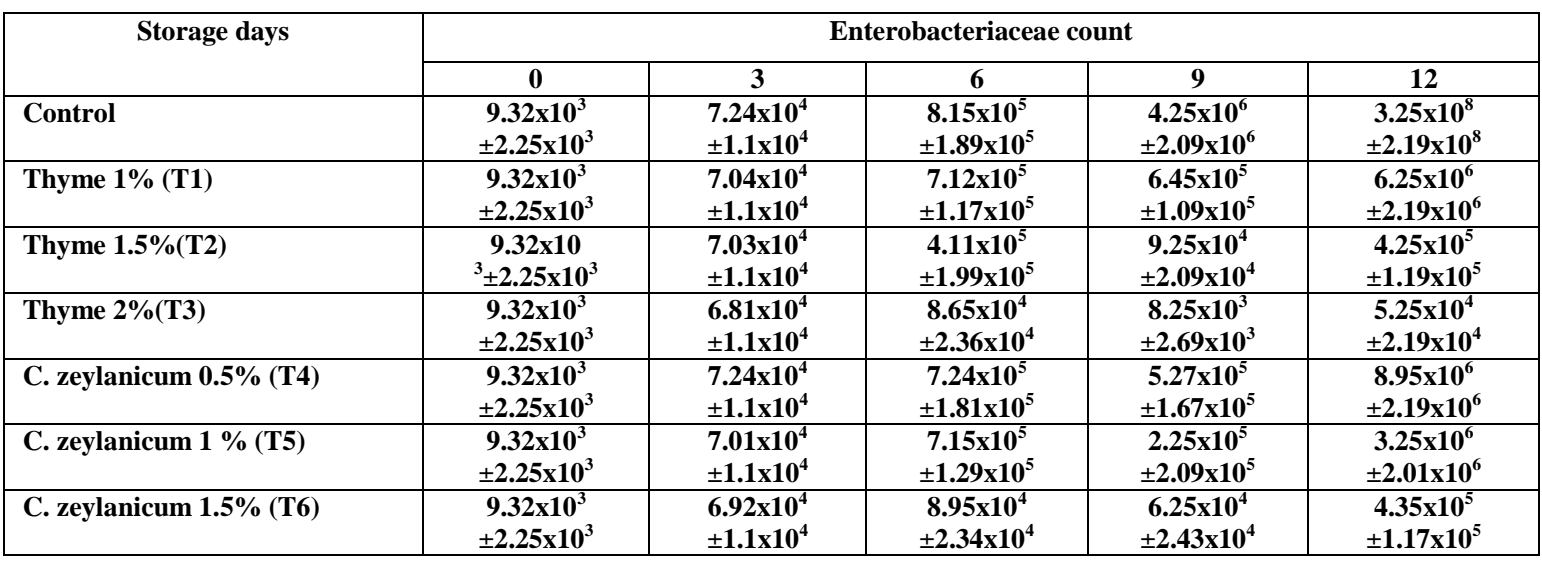

Table(6): Changes in coli form count of examined minced meat during cold storage at $2^{\circ} \mathrm{C}$ (Mean $\pm \mathrm{SE}$ ).

\begin{tabular}{|l|c|c|c|c|c|}
\hline \multicolumn{1}{|c|}{ Storage days } & 0 & 3 & 6 & 9 & 12 \\
\hline Control & $6.45 \times 10^{3}$ & $4.23 \times 10^{5}$ & $3.45 \times 10^{6}$ & $5.53 \times 10^{7}$ & $6.45 \times 10^{8}$ \\
& $\pm 1.21 \times 10^{3}$ & $\pm 1.01 \times 10^{5}$ & $\pm 1.46 \times 10^{6}$ & $\pm 1.11 \times 10^{7}$ & $\pm 1.19 \times 10^{8}$ \\
\hline Thyme 1\% (T1) & $6.45 \times 10^{3}$ & $3.21 \times 10^{5}$ & $2.45 \times 10^{5}$ & $6.13 \times 10^{5}$ & $6.15 \times 10^{6}$ \\
& $\pm 1.21 \times 10^{3}$ & $\pm 1.01 \times 10^{5}$ & $\pm 1.26 \times 10^{5}$ & $\pm 1.11 \times 10^{5}$ & $\pm 1.19 \times 10^{6}$ \\
\hline Thyme 1.5\% (T2) & $6.45 \times 10^{3}$ & $4.53 \times 10^{4}$ & $3.35 \times 10^{5}$ & $3.03 \times 10^{5}$ & $5.45 \times 10^{6}$ \\
& $\pm 1.21 \times 10^{3}$ & $\pm 1.51 \times 10^{4}$ & $\pm 1.16 \times 10^{5}$ & $\pm 1.11 \times 10^{5}$ & $\pm 1.19 \times 10^{6}$ \\
\hline Thyme 2\% (T3) & $6.25 \times 10^{3}$ & $3.23 \times 10^{4}$ & $2.15 \times 10^{4}$ & $8.53 \times 10^{5}$ & $4.45 \times 10^{5}$ \\
& $\pm 1.21 \times 10^{3}$ & $\pm 1.03 \times 10^{4}$ & $\pm 1.06 \times 10^{4}$ & $\pm 1.11 \times 10^{5}$ & $\pm 1.18 \times 10^{5}$ \\
\hline C. zeylanicum 0.5\% (T4) & $6.45 \times 10^{3}$ & $4.13 \times 10^{4}$ & $5.25 \times 10^{5}$ & $9.23 \times 10^{5}$ & $6.25 \times 10^{6}$ \\
& $\pm 1.21 \times 10^{3}$ & $\pm 1.02 \times 10^{4}$ & $\pm 1.22 \times 10^{5}$ & $\pm 1.11 \times 10^{5}$ & $\pm 1.19 \times 10^{6}$ \\
\hline C. zeylanicum 1\% (T5) & $6.45 \times 10^{3}$ & $2.43 \times 10^{4}$ & $3.15 \times 10^{5}$ & $2.44 \times 10^{5}$ & $6.05 \times 10^{6}$ \\
& $\pm 1.21 \times 10^{3}$ & $\pm 1.01 \times 10^{4}$ & $\pm 1.86 \times 10^{5}$ & $\pm 1.11 \times 10^{5}$ & $\pm 1.19 \times 10^{6}$ \\
\hline C. zeylanicum 1.5\% (T6) & $6.45 \times 10^{3}$ & $4.12 \times 10^{4}$ & $6.45 \times 10^{5}$ & $5.63 \times 10^{5}$ & $5.55 \times 10^{6}$ \\
& $\pm 1.21 \times 10^{3}$ & $\pm 2.01 \times 10^{4}$ & $\pm 1.26 \times 10^{5}$ & $\pm 1.21 \times 10^{5}$ & $\pm 1.16 \times 10^{6}$ \\
\hline
\end{tabular}

Table (7):Mean scores of sensory characteristics of examined minced meat during cold storage period at $2^{\circ} \mathrm{C}$.

\begin{tabular}{|c|c|c|c|c|c|}
\hline \multirow{2}{*}{ Sensory attributes } & \multicolumn{5}{|c|}{ Sensory scores } \\
\cline { 2 - 6 } & 0 & $3^{\text {rd }}$ & $6^{\text {th }}$ & $9^{\text {th }}$ & $12^{\text {th }}$ \\
\hline control & Excellent & Fair & poor & Very poor & $\begin{array}{c}\text { Very very } \\
\text { poor }\end{array}$ \\
\hline T1 & Excellent & Good & medium & fair & poor \\
\hline T2 & Excellent & Good & medium & fair & poor \\
\hline T3 & Excellent & $\begin{array}{c}\text { Very very } \\
\text { good }\end{array}$ & Very good & good & medium \\
\hline T4 & Excellent & Good & medium & fair & poor \\
\hline T5 & Excellent & Very good & good & Medium & fair \\
\hline T6 & Excellent & $\begin{array}{c}\text { Very very } \\
\text { good }\end{array}$ & Very good & good & medium \\
\hline
\end{tabular}




\section{DISCUSSION}

From results in table (1) which showed that samples containing thyme essential oil were lowering in $\mathrm{pH}$ values than control samples during different periods of storage test . Also, by increasing concentration of thyme to $2 \%$ scored highest effect in lowering $\mathrm{pH}$ value than lower concentration (1\%). These results were nearly similar to results obtained by Salem et al. (2010) who reported that minced beef mixed by thyme essential oil during cold storage at $4{ }^{\circ} \mathrm{C}$ withdifferent concentrations of thyme $(1.5 \%, 1 \%$ and $0.5 \%)$ showed significant effect in lowering of $\mathrm{pH}$ values than those of untreated samples, also the highest oil's concentration was more effective in lowering $\mathrm{PH}$ values than lower concentrations were used. These agreement with, Kassemet al. (2011) they stated that $\mathrm{pH}$ values of burger samples treated with high concentration of thyme $(1.2 \%)$ were significantly low $(p<0.05)$ comparing with control samples after4 days of storage at refrigeration temperature, might be due to the antimicrobial effect of phenolic compound in herb oil. By using cinnamon oil, the obtained results indicated that $\mathrm{PH}$ values at different concentrations of cinnamon showed lowering $\mathrm{pH}$ values than control samples, also by increasing of cinnamon(C.zeylanicum) oil concentrations $(1.5 \%)$ results showed more lowering in values than lower cinnamon concentrations $(0.5 \%)$, which may be due to antimicrobial load.These agreement with Yassin - Nessrien, (2003); Gahruie et al.(2017) and Kesavan et al.(2014) who stated that $\mathrm{pH}$ values of raw beef meat samples were measured during storage at $4 \pm 1^{\circ} \mathrm{C}$ for 15 days had higher $\mathrm{pH}$ value at control samples than samples treated by cinnamon oil, this increase in $\mathrm{pH}$ reflects the degree of meat spoilage through protein breakdown for the production of free amino acids, leading to theformation of $\mathrm{NH} 3$ and amines, compounds of alkaline reactions. Also, these results agreement with that obtained by Brilliana et al. (2017) they stated that the addition of cinnamon essential oil on ground beef can lowering $\mathrm{pH}$ values of fresh ground beef during refrigerated storage compared to the controlsample, these results because of the active components of the cinnamon essential oil that are cinnamaldehyde, linalool and eugenol.

From results in table (2) which showed that treated samples with thyme oil at different concentrations showed lowering in TBARs values than control samples and increasing of thyme essential oil concentration caused decreasing the TBARs values than lower thyme concentration used. Such findings may be attributed to the high antioxidant effect of thyme essential oil, which is related to the scavenger nature of its flavonoids and phenolic content as apigenin, naringenin, luteolin, thymonin, carvacrol and thymol (Senatore, 1996). Also these results were similar to that was obtained by Salem et al(2010) ; Kassem et al (2011) and Zengin et al .(2015) who mentioned that TBA values of minced meat were obtained over 9 days of storage at $4^{\circ} \mathrm{Cand}$ TBA values of control showed a rapid increase with increasing storage time, TBA values of thyme treatment samples on day 0 were significantly lower $(\mathrm{P}<0.05)$ than those for the control sample. Moreover, treatment samples had significantly lower $(\mathrm{P}<0.05)$ TBA values than control at each day of testing throughout sixth and ninth days of the storage period. Also, Ghaderi et al. (2016) who mentioned that changes in TBARS value of beef burgers with different formulations during 8 days of refrigerated storage the amount of TBARs increased suddenly over time in control burgers, and significant differences were evident among treated samples with thyme oil as compared to control samples. By usind cinnamon oil, all treated samples by 
cinnamon oil showed lowering in TBARs values than control sample, also increasing concentration of C.zeylanicum essential oil caused decreasing in the TBARs values than lower concentration of the same oil. This result agrees with results obtained by Pikul et al., (1984);Ciftci et al., (2010); Ojagh et al., (2010) and Andevari and Rezaei(2011). These results agree with Kesavan et al. (2014) who recorded that the effect of cinnamon oil on TBARS values of raw beef samples during storage at $4^{\circ} \mathrm{C}$ for 15 days. TBARS values of all treated samples were considerablylower $(\mathrm{P}<0.05)$ than those of control samples during storage, indicating high protection by the spice extracts against lipid oxidation in raw beef meat samples. Also, Irfiana etal. (2017) mentioned that cinnamon oil showed decreasing at TBA values of vacuum-packed ground beef during refrigerated storage (at 0 , 4, 8, 12, and 16 day) when compared with TBA values of control samples, as cinnamon oil contains active compounds such as polyphenols, cinnamaldehyde leading to antibacterial action and antioxidant of meat.

From results in table (3) which showed that from the obtained result which appeared that the treatment samples with thyme oil at different concentrations caused decreasing in TVN values than results showed by control samples, also by increasing concentration of thyme (2\%) was more effective in decreasing TVN values than lower concentration of thyme (1\%), the degree of autolysis and bacterial proteolysisin meat can be measured as TV which actually determines the quantity of amino acids, i.e., tyrosine and tryptophan present in an extract of meat. Nearly agree with the results which were obtained by Salem et al.(2010) who mentioned that preserved minced beef at $4^{\circ} \mathrm{C}$ during 6 days of storage period recorded the highest rate of TVN values at control samples, also the treated sample with $1.5 \%$ thyme oil was more effective in decreasing TVN values than sample treated with $0.5 \%$ thyme oil, due to the role of thyme oil on microbial population and bacterial growth as antimicrobial agents. By using cinnamon oil, from the obtained result which appeared that the treatment samples with cinnamon oil at different concentrations caused decreasing in TVN values than control samples, also by increase concentration of cinnamon $(1.5 \%)$ was more effective in decreasing TVN values than lower concentration of cinnamon $(0.5 \%)$ which was used. These results were agree with results were recorded by Quattara et al.(2000) and Biswas et al.(2011)who recorded that lowering TVN values of meat when treated by cinnamon oil than control samples was due to cinnamaldehyde.

From results in table (4) which showed that from the obtained results, samples treated by different concentrations of thyme showed decreasing count of aerobic plate microorganism when compared to control samples, also high concentration of thyme more effective in decreasing this count than lower concentration. These results were similar to results were obtained by Salem et al.(2010) ; Elgaafary et al.(2016) and Amani (2017) who mentioned that the antibacterial effect of thyme oil in refrigerated minced beef as decreasing APC than control sample. High concentration of thyme oil $(1.5 \%)$ was more effective on decreasing APC values than values of lower concentration of the same oil $(0.5 \%)$. By using cinnamon oil, from the obtained results, samples treated with different concentrations of cinnamon caused decreasing count of aerobic plate microorganism when compared to control samples, also high concentration of cinnamon $(1.5 \%)$ was more effective in decreasing this count than lower concentration of cinnamon oil $(0.5 \%)$. These results were agree with results were obtained by Krishnamoorthy et al.(2004)they stated that cinnamon (C.zeylanicum) oilconsists of two chemical 
volatile phenols and poly phenols. Cinnamon showed as antibacterial properties against gram positive and gram negative bacteria. Also, agree with Irfiana et al. (2017) who recorded that cinnamon oil showed decreasing count of total plat count microorganisms of vacuum-packed ground beef during refrigerated storage (at $0,4,8,12$, and 16 day) when compared with count of control samples, due to cinnamon contains active compounds such as polyphenols, cinnamaldehyde and antibacterial compounds.

Results in table (5) showed that samples treated by different concentrations of thyme oil showed decreasing count of enterobacteriaceae when compared to control samples, also high concentration of thyme (2\%) was more effective in decreasing this count than lower concentration(1\%). These results nearly similar to results were obtained by Bozen et al. (2006) ; Yassin- Nessrien and Abou-Taleb(2007). Also, Salem et al.(2010) stated that preserved minced beef at $4^{\circ}$ Calonge 6 days storage period at the control samples had the highest counts of enterobacteriacea compared to other treatment of minced beef by different concentration of thyme $(0.5 \%, 1 \%, 1.5 \%)$. Also, the highest concentration of thyme (1.5\%) appeared more decreasing of enterobacteriacea count than lower concentration of thyme $(0.5 \%)$. Also, Amani (2017) who recorded that preserved minced beef at refrigeration temperature, with treatment by thyme oil play an important role in decreasing enterobacteriacea count especially at $1.5 \%$ concentration.

By using cinnamon oil, from the obtained results, samples treated by different concentrations of cinnamon oil caused decreasing count of enterobacteriacea when compared to control samples, also high concentration of cinnamon was more decreasing of (EBC) than lower concentration of cinnamon $(0.5 \%)$. These results were nearly similar to results were obtained by Quattara et al. (2000) who mentioned that treatment cooked meat products by trans- cinnamaldehyde, which is main component of cinnamon oil ,produced significant extension of cooked meat products shelf life by inhibiting growth of enterobacteriacea.

Table (6) showed that from the obtained results, samples treated by different concentrations of thyme oil showed decreasing count of coliform when compared to control samples, also high concentration of thyme oil (2\%) was more effective in decreasing this count than lower concentration (1\%) . These results were nearly similar to that obtained by Hoque et al.(2008) ; Solomakos et al.(2008); Krischetal. (2010) and Boskovic et al.(2015) .Also, Emiroglu et al. (2010) who mentioned that thymol is effective to destroy coliforms when used at concentration of 250,500 and $750 \mathrm{mg} / \mathrm{kg}$ of beef minced patties and stored for 16 days under ordinary or modified packaging at refrigeration temperature, also mentioned that covering surface of meat products by $0.8 \%$ thymol, thecount of coliforms decreased by 2-3 log units. Also Salem et al. (2010) stated that preserved minced beef at $4^{\circ} \mathrm{C}$ alonge 6 days storage period, the control sample had the highest counts of coli forms compared to other treatment of minced beef by different concentration of thyme $(0.5 \%, 1 \%, 1.5 \%)$, highest concentration of thyme (1.5\%) appeared more effectiveness in decreasing coliforms count especially at $3^{\text {rd }}$ and $6^{\text {th }}$ day of storage period than lower concentration (0.5\%). Also, Amani (2017) who recorded that preserved minced beef at refrigeration temperature, with treatment by thyme oil play an important role in decreasing coliforms count especially at $1.5 \%$ concentration. By using cinnamon oil, from the obtained results, samples treated by different concentrations of cinnamon oil caused decreasing count of 
coliform when compared to control sample, also high concentration of cinnamon $(1.5 \%)$ was more effective in decreasing this count than lower concentration $(0.5 \%)$. These results were nearly similar to results were obtained by Hoque et al.(2008); Friedman et al. (2002); Hoque et al.(2007); Charu Gupta et al .2008) and Reham, (2013) who stated that treatment of minced beef under cool temperature $4^{\circ} \mathrm{C}$ by using of cinnamon (C.zeylanicum) oil at different concentrations $(0.5 \%, 1 \%, 1.5 \%)$ showed decreasing count of coliform when compared to control sample, also high concentration of cinnamon (1.5\%) more effective in decreasing this count than lower concentration(0.5\%). Also, Jagadeesh et al.(2013) who mentioned that cinnamon oil decreased coli form count, might be due to cinnamaldehyde and the antimicrobial compound of cinnamon.

Results in table (7) revealed that sensory properties of different treated minced beef samples during cold storage $\left(2^{\circ} \mathrm{C}\right)$ were enhanced by using thyme and cinnamon oils compared to the untreated (control) samples at0 day, $3^{\text {rd }}$ day, $6^{\text {th }}$ day, $9^{\text {th }}$ day and $12^{\text {th }}$ day of the storage period, respectively. Generally, samples containing $2 \%$ thyme oil and $1.5 \%$ cinnamon oil, demonstrated the highest enhancement of sensoryattributes, while the samples treated with $1 \%$ of thyme and $0.5 \%$ of cinnamon oils demonstrated lower enhancement. This result agrees with that obtained by Sasse et al. (2009) who reported that many herbs and spices as thyme contain antioxidant components that improve both color and flavor stability in meat. Also, Salem et al. (2010) mentioned that sensory properties of minced beef samples during cold storage $\left(4^{\circ} \mathrm{C}\right)$ were enhanced by treatment minced beef by different concentrations of thyme oil $(0.5 \%, 1 \%$, $1.5 \%$ ) compared to the untreated ( control) samples, and sample contain $1.5 \%$ thyme oil revealed best enhancement of sensory properties than sample contain $0.5 \%$ of the same oil , at zero, $3^{\text {rd }}$, and $6^{\text {th }}$ day of the storage period, respectively. Also Ibrahim et al. (2016) mentioned that the sensory properties of different treated minced beef samples during cold storage $\left(4^{\circ} \mathrm{C}\right)$ were improved by using different concentrations $(.5 \%, 1 \%$ and $1.5 \%)$ of thyme oil compared to the control samples after 3hrs, 1st, 2nd, 3rd, 4 th and 5th day of the storage period, also sample containing $1.5 \%$ thyme demonstrated the highest enhancement of sensory attributes than sample treated with $0.5 \%$ of the same oil. Also Amani etal. (2017)they reported that the sensory properties of different treated minced beef samples by using thyme oil at concentrations $(0.5 \%, 1 \%, 1.5 \%)$ and cinnamon oil at concentrations $(0.5 \%, 1 \%$, $1.5 \%)$ during cold storage $\left(4^{\circ} \mathrm{C}\right)$ were enhanced at treatment samples compared to the untreated ( control) samples at zero, $1^{\text {st }}$, $2^{\text {nd }}, 3^{\text {rd }}$ and $4^{\text {th }}$ day of the storage period, also samples containing $1.5 \%$ (cinnamon and thyme) oils demonstrated the highest enhancement of sensory properties.

\section{5- Conclusion}

Thyme and cinnamon oils can be used as natural meat preservatives with antimicrobial activities against food borne pathogens, and therefore may be useful in maintaining the meat quality, extending shelf- life of meat, preventing economic loss and providing the consumer with food containing natural additives especially at thyme (2\%) and cinnamon $1.5 \%$.

\section{6- REFERENCES}

Amani, M. Salem; Zakaria E. M. and Abd El Raheem, K. A. 2017.Efficiency of some essential oils in control of methicillin resistant Staphylococcus aureus (MRSA) in Minced Beef. Faculty of Veterinary Medicine, Benha University, 
Egypt, Animal Health Research Institute, Dokki, Egypt (BVM) J, 32 (1): 177-183.

Andevari G.T.; Rezaei M. 2011.Effect of gelatin coatingincorporated with cinnamon oil on the quality of freshrainbow trout in cold storage. International Journal of Food Science \& Technology, 46: 2305-2311.

APHA (American Public Health Association) (1985): Standard methods for the examination of dairy products. 15th Ed., New York, USA.

Baratta, M.T.; Dorman, H.J.D.; Deans, S.G.;Figueiredo, A.C.;Barroso, J.G. and Ruberto, G. 1998. Antimicrobial and antioxidant properties of some commercial essential oils. Flavor and Fragrance Journal, 13: 235-244.

Barbosa,L.N.; Rall,V.L.M.; Fernandes,A.A.H.; Ushimaru,P.I.; Probst,I.S. and Fernandes,A., Jr. 2009. Essential oils against foodborne pathogens and spoilage bacteria in minced meat.Foodbornpathog. Dis, 6:725-728.

Bensid, A.; Ucar, Y.; Bendeddouche, B. and Özogul, F. 2014. Effect of the icing with thyme, oregano and clove extracts on quality parameters of gutted and beheaded anchovy (Engraulisencrasicolus) during chilled storage. Food Chem., 145: 681-686.

Biswas, S.; Chakraborty, A.; Patra, G. and Dhargupta, A. 2011. Quality and acceptability of duck patties stored atambient and refrigeration temperature. Int. J. Livest. Prod., 1(1): 1-6.

Boskovic, M.; Zdravkovic, N.;Ivanovic, J.;Janjic, J.; Djordjevic, J.; Starcevic,M. and Baltic,M.Z. 2015. Antimicrobial activity of Thyme(Thymus vulgaris) and Oregano (Origanum vulgare) essential oils against some food-borne microorganisms.Procedia Food Sci., 5:18-21

Bozin, B.; Mimica-Dukic, N.;Simin,N, Anackov, G.2006. Characterization of the volatile composition of essential oils of some Lamiaceae spices and the antimicrobial and antioxidant activities of the entire oils. J. Agric. Food Chem., 54(5): 1822-1828.

Brilliana, N.; Manuhara, G.J.; Utami, U.\&Khasanah, L.U.2017.The effect of cinnamon bark (cinnamomumburmanii) essential oil microcapsules on vacummed ground beef quality. International Conference on Food Science and Engineering UniversitasSebelasMaret, Jl. IrSutami 36A,Surakarta, Central Java, Indonesia. IOP Conf. Series: Materials Science and Engineering. 193

Charu- Gupta; Amar, P.; Garg, Ramesh, C.; Uniayal, and Kumari, A. 2008. Comparativeanalysis of theantimicrobial activity of cinnamon oiland cinnamon extract on some foodborne microbes. African Journal ofMicrobiology Research, 2: 247-251.

Ciftci, M.; Simsek, U.G.; Yuce, A.; Yilmaz, O. and Dalkilic, B.2010.Effects of Dietary Antibiotic and Cinnamon Oil Supplementation on Antioxidant Enzyme Activities, Cholesterol Levels and Fatty Acid Compositions of Serum and Meat in Broiler Chickens.Acta Vet. Brno, 79: 33-40.

Donsi,F.;Annunziata,M.;Sessa,M.; errari,G.2011.Nanoencapsulation of essential oils to enhance their antimicrobial activity in foods. Food Science and Technology, 44:1908-1914. 
Dorman, H.J.and Deans, S.G. 2000. Antimicrobial agents from plants: antibacterial activity of plant volatile oils. Journal of Applied Microbiology, 88:308-316.

Elgaafary,O.M.; El-Atabany,A.; Darwish ,W.S. and El Abbasy, M. T.2016. Using of some volatile oils for improving the quality of some meat products. Food Control Department, Faculty of Vet.Medicine, Zagazig University, pg.58-74.

Emiroglu, Z.K.; Yemis,G.P.;Coskun,B.K. and Candogan,K. 2010. Antimicrobial activity of soyedible films incorporated with thyme and oregano essential oils on fresh ground beef patties. sci., 86:283-288.

FAO (Food and AgricultureOrganization of the United Nations) (1980): Manual of food quality control, 3- commodities. United Nations, Rome.

Friedman, M.; Henika, P.R. and Mandrell, R.E. 2002.Bactericidal tivitiesofplantessential oils and some oftheir isolated constituents againstCampylobacterjejuni,

Escherichiacoli , Listeria monocytogenesandSalmonellaenterica. Journal ofFood Protection, 65: 15451560.

Gahruie,H.H.;Hosseini,H.M.S.;Taghavifard,H .M.;Eskandari,H.M.;Golmakani,T.M. and Shad,E.2017. Lipid Oxidation, Color Changes, and MicrobiologicalQuality of Frozen Beef Burgers Incorporated with ShiraziThyme, Cinnamon, and Rosemary Extracts. Journal of Food QualityVolume 2017, Article ID 6350156, 9 pages.
Ghaderi,M.G.;Barzegar,M.;Sahari,M.A.andA zizi,M.H.2016. Nanoencapsulation Approach to Improve Antimicrobial and Antioxidant Activity of Thyme Essential Oil in Beef Burgers during Refrigerated Storage. Food and Bioprocess Technology, Volume 9, Issue, 7: pp 1187-1201.

Gutierrez,J. Barry-Ryan,C. and Bourke,P. 2008. The antimicrobial efficacy of plant essential oil combinations and interactions with food ingredients. Int. J. Food Microbiology, 124: 91-97.

Gutierrez,J. Barry-Ryan,C. and Bourke,P. 2009. Antimicrobial activity of plant essential oils using food model media: Efficacy, synergistic potential and interactions with food components. Food Microbiology, 26:142-150.

Gomez, K. A. and Gomez, A. A. 1984.Statistical procedures for agriculture research. John Wiliy and Sons Editor Inc. USA (2Ed.), Chapter 3: 129-184.

Hoque, M. D.; Inatsu, M. L.; Juneja, Vijay and Kawamoto, S. 2007. Antimicrobial activity of clove and cinnamon extracts against food borne pathogens and spoilage bacteria and inactivation of Listeria monocytogenes in ground chicken meat with their essential oils. J. Food Sci. \& Tech., 72: 9-21.

Hoque, M.; Bari, M. L.; Juneja V. K. and Kawamoto, S. 2008. Antimicrobial activity of clove and cinnamon extract against food borne pathogens and spoilage bacteria, and inactivation of listeria monocytogenes in ground chicken meat with their essential oils. Nat. Food Res. Inst., 72:9-21.

Houben,J.H.; van Dijk,A.;

Eikelenboom,G.\&Hoving- 
Bolink,A.H.2000.Effect of vitamine E supplementation, fat level and packaging, 331-336.

Ibrahim-Hemmat,M.; El Sabagh-Rasha, A. Abou El-Roos-Nahla, A.; Abd El Fattah-Hend 2016.Antimicrobial effect of some essential oils on Staphylococcus aureus in minced meat. Benha Veterinary Medicine, Journal, Vol. 30, No.1:183-191.

ICMSF (International Commission on Microbiological Specifications for Foods) 1996.Microorganisms in foods.Black Academic and Professional, London.

Irfiana,D.;

Utami,R.;Khasanah,L.U.andManuhara, G.J.2017. Preservation Effect of TwoStage Cinnamon

Bark(CinnamomumBurmanii)

Oleoresin Microcapsules OnVacuumPacked Ground Beef During Refrigerated Storage. Food Science and Technology,

UniversitasSebelasMaret,Surakarta, doi: $10.1088 / 1757$

ISO 1979. International Standards, ISO2917, Meat and meat products: Measurement of $\mathrm{pH}$.

Jagadeesh, A. Babu,;Maheswara, D.; Reddy and swara, B.E. Rao 2013. EFFECT OF ESSENTIAL OILS OF GARLIC, CLOVE AND CINNAMON ON ESCHERICHIA COLI IN CHICKEN MEAT NUGGETS Tamilnadu J. Veterinary and Animal Sciences, 9 (1): $74-81$.

Jayasena, D.D. and Jo, C.2013. Essential oils as potential antimicrobial agents in meat and meat products: A review. Trends Food Sci. Technol., 34:96-108.
Jham, G.N.; Dhingra, O.D.; Jardin, C.M. and Valente, M.M. 2005. Identification of the major fungi toxic component of cinnamon bark oil. Fitopatol Bras., 30: 404-408.

Kassem, G.M.; Atta-Alla, O.A. and Ali, f.h.m.2011. improving the quality of beef burger by adding thyme essential oil and jojoba oil .Arch .Zootec, 60(231):787795.Egypt.

Kesavan,R.k.;Srinivasan,B.;Packirisamy,A.S. B.;Mohammed,A.F.;Kalleary,S.; Ganesan, A.;Meenatchisundaram S. and Muthusamy S.2014. Bio protection and preservation of raw beef meat using pungent aromatic plant substances. Society of Chemical Industry J. Sci. Food Agric., 94: 2456-2463.

Krisch, J.; Pardi, Z.; Tserennadmid, R.; Papp, T., and Vagvolgyi, C.2010.Antimicrobial effects of commercial herbs, spices and essential oils in minced pork. Volume ActaBiologicaSzegediensis, 54(2): 131134.

Krishnamoorthy, B. and J, Rem.2004.End uses of cinnamon and cassia in Cinnamon and Cassia.The Genus Cinnamomum; Ravindran, P.N. and K.N. Babu. Eds.; CRC Press: Boca Raton, FL, USA.

Ojagh S.M.; Rezaei M.; Razavi S.H.; Hossein,S.M.H. 2010. Effect of chitosan coatings enriched with cinnamon oil onthe quality of refrigerated rainbow trout. Food Chemistry, 120: 193-198.

Pearson, A.M. and Tauber, F.W. (1984): Processed Meats. 2nd AVI Publishing company, Inc.

Pikul, J.; Leszcynski, D.E.; Niewiarowicz, A. and Kummerow, F.A. 1984. Lipid oxidation in 
chicken breastand leg meat after sequential treatments of frozen storage, cooking, refrigerated storage and reheating. J. FoodTechnol., 19: 575-580.

Quattara,B.; Simard,R.E.; Piette,J.-P.G.; Begin ,A. \&Holley,R.A.2000. Inhibition of surface spoilage bacteria in processed meats by application of antimicrobial films prepared with chitosan. International Journal of Food Microbiology, 62:139-148.

Rather, S.A.; Masoodi, F.A.; Akhter, R.; Gani, A.; Wani, S.M. and Malik, A.H. 2016.Effects of sugar as fat replacer on some quality parameters of mutton goshtaba, a traditional Indian meat product. Small Ruminant Research,137:169-176. doi:10.1016/j.smallrumres.03.013.

Reham, A.A. 2013.Screening of antibacterial activity of Cinnamon, Clove and Rosemary essential oils against common food borne pathogens in minced beef meat.Benha Veterinary Medical J,25:151-1642.

Salem-Amany, M.; Amine-Reham, A.; and A. Gehan, S. 2010.Studies on Antimicrobial and Antioxidant Efficiency of Some Essential Oils in Minced Beef. Journal of American Science, 6 (12):691-202.

Sasse, A.; Colindres, P.and Brewer, M.S. 2009. Effect of natural and synthetic antioxidants on oxidative stability of cooked, frozen pork patties. J. Food Sci., 74(1): S30-S35.

Senatore, F. 1996. Influence of harvesting time on yield and composition of the essential oil of thyme growing wild in Campania South Italy. J. Agr. Food Chem., 44: 1327-32.
Skandamis, P. N. and Nychas, G. J. 2001.Effect of oregano essential oil on microbiological and physicochemical attributes of minced meat stored in air and modified atmospheres. Journal of Applied Microbiology, 91: 1011-1022.

Solomakos, N.; Govaris, A.; Koidis, P. and Botsoglou, N. 2008. The antimicrobial effect of thyme essential oil, nisin, and their combination against Listeria monocytogenes in minced beef during refrigerated storage. J. Food Microbiology, 25 (1): 120- 127.

Stahl-Biskup, E. 1991.The chemical composition of thyme oils. A review of the literature 1960-89.J. Essential Oil Res., 3: 61-82.

Vyncke, W. 1970. Direct determination of the thiobarbituric acid value in trichloroacetic acid extracts of fish as a measure of oxidative rancidity. FetteseifenAstrichmitted, 2: 10841094.

Yassin -Nessrien, M. N. 2003.Effect of storage conditions on the quality parameters of differently treated fish. Ph. D. Thesis, Fac. Agric. Ain Shams, Univ. Cairo. Egypt.

Yasin, Nessrien, M.N. and Abou-Taleb, M.2007. Antioxidant and antimicrobial effects of Marjoram and thyme in coated refrigerated semi fried mull et fish fillets. World J. Dairy\& Food Sci., 2(1):1-9.

Zengin, H. and Ayse Handan Baysal 2015.Antioxidant and Antimicrobial Activities of Thyme and Clove Essential Oils and Application in Minced Beef. Journal of food processing and preservation, View issue TOC Volume 39: Issue 6 December 2015 Pages 1261-1271. 